\title{
Tree species diversity, distribution and population structure in a tropical dry deciduous forests of Chhatisgarh, India
}

\author{
Chaman Lal $^{1^{*}}$, Lalji Singh ${ }^{2}$, Varun Attri ${ }^{3}$ and S. Sarvade ${ }^{3}$ \\ ${ }^{1}$ Department of Social Sciences, Dr. Y.S. Parmar University of Horticulture and Forestry, (H.P.), INDIA \\ ${ }^{2}$ Department of Forestry, College of Agriculture, I.G.K.V., Raipur (C.G.), INDIA \\ ${ }^{3}$ Department of Silviculture and Agroforestry, Dr. Y.S. Parmar University of Horticulture and Forestry, \\ Solan (H.P.), INDIA \\ *Corresponding author. E-mail: negi.chaman9@gmail.com
}

Received: February 23, 2015; Revised received: July 2, 2015; Accepted: August 30, 2015

\begin{abstract}
Tree species diversity, distribution and population structure of tropical forests of Bharnawapara wildlife sanctuary was investigated. The study analyzed the structure of a tropical dry deciduous forest in Chhatisgarh at different sites i.e. closed natural forest, open natural forest and plantation forests of teak. The study was conducted by laying 30 quadrats, each $10 \mathrm{~m} \times 10 \mathrm{~m}$ in size at different sites. In total, 246 trees belonging to 28 species of 17 families were recorded from 0.3 ha sampling area. Density ranged between 520 to 990 trees ha $^{-1}$ subsequently, basal area ranged between 21.50 to $47.30 \mathrm{~m}^{2} \mathrm{ha}^{-1}$. The dominant tree species was Cleistanthus collinus with an importance value index (IVI) of 57.70. Other important species were Terminalia tometosa (IVI 47.10), Lagerstroemia parviflora (36.92), Diospyros melanoxylon (28.42) and Madhuca indica (26.03). The Shannon-Wiener index ( $\left.\mathrm{H}^{\prime}\right)$ ranged between 0.19 to 3.35 and Simpson's index $(\mathrm{C})$ between 0.12 to 0.95 indicating high tree species diversity of tropical dry deciduous forests. It is evident from the study that natural forest has an edge over plantation forest in terms of species diversity, dominance and richness. Tree species diversity, distribution and population structure provide baseline information for conservation and management of tropical dry deciduous forests in India. Efforts are needed to conserve the natural forest for their diversity and existence. They can also be supplemented with plantation forests to lower the biotic pressure.
\end{abstract}

Keywords: Basal area, Dry deciduous, Importance value index. Plant diversity, Population structure

\section{INTRODUCTION}

Tropical forests are characterized by high species richness, standing biomass and productivity (Jordan, 1971a) and their diversity has attracted much attention in recent years (Sagar et al. 2003; Sahu et al., 2008). In most develop-ing countries, including India, even protected forests experience extensive anthropogenic disturbance due to grazing, extraction of fuel wood and collection of non-wood forest products which contribute to the livelihood of forest dwelling populations (Singh et al., 1997; Hegde and Enters, 2000; Pattanayak et al., 2003). The degree of anthropogenic disturbance may differ in different parts of a conservation area (Kolongo et al., 2006) and it is argued that continuing biomass extraction activities may thwart the goal of biodiversity conservation (van Schaik et al., 1997). In intermediate disturbance can potentially increase species richness in old-growth communities (Sheil, 1999). Disturbance in terms of Fires have negative impacts on native plant diversity, with varying effects on species and ecosystems, including the potential for localized extinction (Kittur et al., 2014) whereas, Jhariya et al., 2012 reports that low fire zone had minimum Shannon index $\left(\mathrm{H}^{\prime}=2.40\right)$ which indicates that medium fire supports the diversity in the forest. However, some ecologists argue that disturbance does not increase diversity in old-growth forests (Phillips et al., 1997). Due to these infringements by the renowned researchers, the present study was carried out in the protected area of Bharnawapara wildlife sanctuary, Chattisgarh. Though it is a protected area there is lots of anthropogenic pressure due to abundance of resources availability. It is imperative to study such areas for the sustainable management of available resources in the light of anthropogenic pressure inside the wildlife sanctuary.

\section{MATERIALS AND METHODS}

Study area: The study was carried out in Barnawapara wildlife sanctuary situated in North corner of Raipur district of Chhattisgarh. The area is located between $21^{\circ} 20^{\prime} 00^{\prime \prime}$ to $21^{\circ} 25^{\prime} 47^{\prime \prime}$ North latitudes and $82^{\circ} 21^{\prime}$ $17^{\prime \prime}$ to $82^{\circ} 26^{\prime} 27^{\prime \prime}$ East longitudes. The topography of area is undulating due to formation of rockout crop. Tilsa Pathar is the highest location of the study area with an altitude of $463 \mathrm{~m}$ above mean sea level. The climate of study area is dry humid tropical consist of three seasons viz. rainy, winter and summer. The average annual rainfall in the study area ranges from ISSN : 0974-9411 (Print), 2231-5209 (Online) All Rights Reserved (C) Applied and Natural Science Foundation www.ansfoundation.org 
1200-1350 mm. It gradually decreases from South -East direction to North-West direction. About 80 percent of the rainfall in the study area is received from south west monsoon during June to August. The highest amount of rainfall occurs in July. Number of rainy days varies from 90-100 days. The mean monthly maximum temperature ranges from $27.3{ }^{\circ} \mathrm{C}$ in January to $41.8{ }^{\circ} \mathrm{C}$ in May and mean monthly minimum temperature ranges from $12.7{ }^{\circ} \mathrm{C}$ in December to $27.3{ }^{\circ} \mathrm{C}$ in May. The mean annual maximum and minimum temperatures of study area are $33.1^{\circ} \mathrm{C}$ and $20.5^{\circ} \mathrm{C}$, respectively. Relative humidity of study area increases with the onset of south-west monsoon and it generally becomes more than $80 \%$ in July. In the post monsoon and winter season the relative humidity lies between $50-65 \%$ in the morning (6:00 to $12: 00$ hrs.) and $30-40 \%$ in the afternoon (12:00 to $16: 00$ hrs.). Relative humidity is lowest during summer and drops below $30 \%$ in the afternoon in April and May.

\section{Methodology}

Vegetation analysis in both i.e. natural forest and teak plantation were studied during 2009-2010. Phytosociological studies were carried out using quadrat method. The total 30 (10 in each site) quadrats of size $10 \mathrm{~m} \times 10 \mathrm{~m}$ were laid down in stratified random manner to study the tree species diversity, distribution and population structure. Species area curve was used to determine minimal sample area which is based on quantitative variation of the vegetation terms of species number (Muellor-Dombios and Ellenberg, 1974). The adequacy of sample size was estimated by stopping sampling at the point at which additional quadrats did not significantly affect the mean of species. In each quadrat, individuals of having $>30 \mathrm{~cm} \mathrm{GBH}$ (girth at breast height, i.e. $1.37 \mathrm{~m}$ above the ground) were considered as trees and measured species-wise. Abundance (A), frequency $(\mathrm{F})$, relative frequency $(\mathrm{RF})$, density (D), relative density (RD), basal area (BA), relative basal area (RBA), importance value index (IVI), Shannon-Wiener index (Shannon and Weaver 1963) and Simpson's index (Simpson, 1949) were calculated following the methods adopted by Misra (1968). IVI of each species was calculated by summing the RF, RD and RBA values following Curtis (1959). Abundance to frequency ratio (A/F) of each species was calculated to study the dispersion pattern. The ranges of values for determining dispersion pattern were: regular $(<0.025)$, random (0.025 - 0.05) and contiguous ( $>0.05)$ (Curtis and Cotta 1956). Population structure of tree species was analyzed across four girth classes i.e. 30-60, 60-90, 90-120 and $>120 \mathrm{~cm}$.

\section{RESULTS AND DISCUSSION}

The vegetation data were analyzed for 28 tree species.

Table 1. Species richness, diversity and equitability in different forest plots at tropical dry deciduous forests of Bharnawapara wildlife sanctuary, Chhatisgarh.

\begin{tabular}{lccc}
\hline Natural Parameters & $\begin{array}{c}\text { Closed natural } \\
\text { forest }\end{array}$ & $\begin{array}{c}\text { Open natural forest } \\
\text { Teak plantation } \\
\text { forest }\end{array}$ \\
\hline Species richness (d) & 4.93 & 4.23 & 0.90 \\
Shannon index (H') & 3.35 & 3.08 & 0.19 \\
Concentration of dominance $(\mathrm{Cd})$ & 0.12 & 0.14 & 0.95 \\
Equitability (e) & 1.12 & 1.17 & 2.39 \\
Beta diversity (Bd) & 3.16 & 5.77 & 3.03 \\
\hline
\end{tabular}

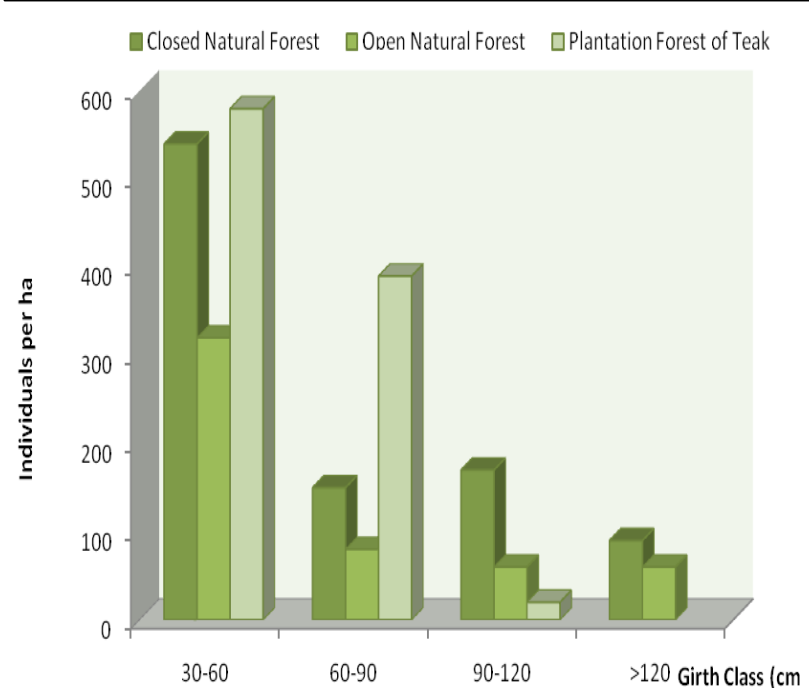

Fig. 1. Different girth class wise distribution of trees in different forest plots at tropical dry deciduous forests of Bharnawapara wildlife sanctuary, Chhatisgarh.
A total of 246 trees belonging to 28 species were recorded from 30 sample plots. In closed natural forest a total of 950 trees $^{-1}$ representing 20 species and 12 families were encountered. The Euphorbiaceae family was represented by 41 individuals followed by Combritaceae and Leguminaceae, 13 species each, in the open forest a total of 520 trees $\mathrm{ha}^{-1}$ representing 14 species and 12 families were encountered and in the plantation forest of teak a total of 990 trees $^{h^{-1}}$ representing 4 species and 4 families were encountered (Table 2). The IVI of dominant tree species was in the order of Cleistanthus collinus (57.70), Terminalia tometosa (47.10), Lagerstroemia parviflora (36.92), Diospyros melanoxylon (28.42) and Madhuca indica (26.03) (Table 2). Twenty one species are contagiously distributed, three species are randomly distributed and four species are regularly distributed (Table 2). Odum (1971) stated that contagious distribution is the commonest pattern of plant distribution in nature. Kumar and Bhatt (2006) reported that most species 
Chaman Lal et al. / J. Appl. \& Nat. Sci. 7 (2) : 681- 685 (2015)

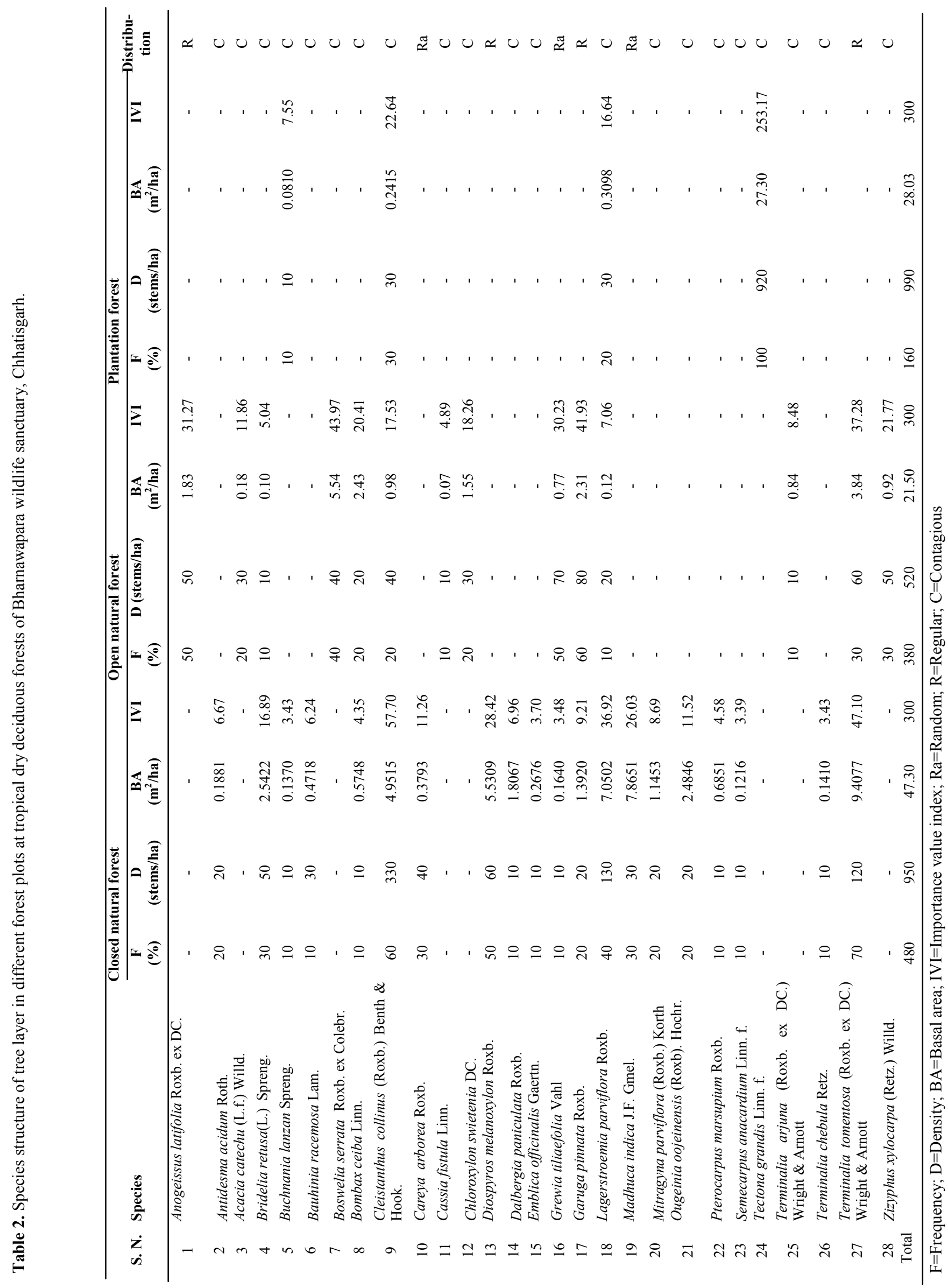


follow contagious distribution pattern in the foot-hill forests of Garhwal Himalaya. Rao et al. (1990) had similar findings for tree species of a sub-tropical forest of north-east India.

Results of diversity parameter revealed that the Shannon index values in different forest types ranged from 0.19 to 3.35 , equitability 1.12 to 2.39 , species richness 0.90 to 4.93 , concentration of dominance 0.12 to 0.95 and beta diversity 3.03 to 5.77 (Table 2). The diversity parameters of these forests are comparable with the diversity indices reported in different tropical forests (Singh and Singh, 1991). Similar findings were also made by Sahu et al. (2012), whose findings for tropical dry deciduous forests of Malyagiri hill ranges, Eastern Ghats were, Shannon-Wiener index $\left(\mathrm{H}^{\prime}\right) 3.38$ and Simpson's index (C) 1.0 indicating high tree species diversity. The Shannon index values of dry tropical forests in study area were comparatively lower than those reported by Singh et al. (1984) tropical forests of India. Singh et al. (1984) reported Shannon index value between 3.4 to 4.8 for tropical rain forests of Silent valley in Western Ghats, India. The lower diversity of dry tropical ecosystem in this study is attributed to sharing of large proportion of resources to only few species $(<27)$, while in tropical evergreen forests more number of species $(>75)$ efficiently shared the resources. The tree density was found maximum in teak plantation followed by closed natural forest and open natural forest in the GBH group of $30-60 \mathrm{~cm}$ and $60-90 \mathrm{~cm}$ (Fig. 1). This might be due to uniform spacing of plantation forests and reduced in 90 $-120 \mathrm{~cm}$ group, as the stand was young i.e. planted during 1974-75. The mean tree density of different sites was $820 \mathrm{ha}^{-1}$. The mean forest density is within the range of 276 - 905 stems $^{-1}$ reported for trees $\geq 15 \mathrm{~cm}$ GBH in other tropical forests (Sahu et al., 2007; Nirmal Kumar et al., 2010; Bhadra et al., 2010 ). The density across different GBH classes shows that the 30 - $60 \mathrm{~cm}$ and $60-90 \mathrm{~cm} \mathrm{GBH}$ classes contributed to $58.54 \%$ and $25.20 \%$ of species richness, respectively (Fig. 1). The mean basal area value of $32.27 \mathrm{~m}^{2} \mathrm{ha}^{-1}$ so obtained in the present study is comparable to the Indian tropical forests (Visalakshi, 1995). Stem density and species richness decreased beyond $90 \mathrm{~cm} \mathrm{GBH}$ class. The highest GBH recorded for $M$. indica $(202.80$ $\mathrm{cm})$ was followed by $D$. paniculata $(150.70 \mathrm{~cm}), B$. serrata $(148.90 \mathrm{~cm}), T$. tomentosa $(143.30 \mathrm{~cm})$ and $O$. oogenensis $(136.70 \mathrm{~cm})$. Also most of the species in study area are contagiously distributed and few were randomly and regularly distributed as calculated through A/F ratio for various sites (Table 2). This is in relation to study carried out by Kittur et al. (2014) in Achanakmar-Amarkantak Biosphere Reserve whose $\mathrm{A} / \mathrm{F}$ values ranged between 0.02 and 0.19 indicating that the most of the species showed contiguous and random distribution and few species were distributed regularly.

\section{Conclusion}

The present study of tropical dry deciduous forests of Bharnawapara wildlife sanctuary, Chhatigarh concluded that the Species diversity index varied between 0.19 to 3.35 and Simpson index of dominance ranged between 0.12- 0.95. The Margalef 's Species Richness Index varied from $0.90-4.93$, equatibility index varied from 1.12-2.39 and $\beta$ diversity varied from 3.03-5.77. Tree species diversity, distribution and population structure analyzed in this study should be useful to the conservationists, researchers and scientists and also to the forest managers for the effective management of the forest ecosystem.

\section{ACKNOWLEDGEMENT}

The author is thankful to staff of Bharnawapara wildlife sanctuary for providing facilities during research. And also grateful to Indian Council of Agriculture Research for providing financial assistance in the form of JRF during M.Sc.

\section{REFERENCES}

Bhadra, A.K., Dhal, N.K., Rout, N.C. and Raja Reddy, V. (2010). Phytosociology of the tree community of Gandhamardan hill ranges. The Indian Forester, 136: 610-620

Curtis, J.T. (1959). The Vegetation of Wisconsin, An Ordination of Plant Communities. University Wisconsin Press, Madison, Wisconsin.

Curtis, J.T. and Cotta, G. (1956). Plant Ecology Workbook, Laboratory Field Manual. Burgess Publishing, Minnesota.

Hegde, R. and Enters, T. (2000). Forest products and household economy: a case study from Mudumalai Wildlife Sanctuary, Southern India. Environmental Conservation, 27: $250-259$.

Jhariya, M.K., Bargali, S.S., Swamy, S.L. and Kittur, B. (2012). Vegetational Structure, Diversity and Fuel Loads in Fire Affected areas of Tropical Dry Deciduous Forests in Chhattisgarh. Vegetos, 25(1): 210-224.

Jordan, C. F. (1971a). Productivity of a tropical forest and its relation to a world pattern of energy storage. J. Ecol., 59: 127-142.

Kittur B., Jhariya M.K. and Lal C. (2014). Is the forest fire can affect the regeneration and species diversity. Eco. Env. \& Cons., 20 (3): pp. 989-994

Kolongo, T.S. D., Decocq, G., Yao, C.Y.A., Blom, E.C. and Van Rompaey, R.S.A.R. (2006). Plant species diversity in the southern part of the Tai National Park (Côte d'Ivoire). Biodiversity and Conservation, 15: 2123-2142.

Kumar, M. and Bhatt, V.P. (2006). Plant biodiversity and conservation of forests in foot hills of Garhwal Himalaya. Journal of Ecology and Application, 11: 43-59.

Misra, R. (1968). Ecology Work Book. Oxford \& IBH Publications, New Delhi.

Muellor-Dombois, D. and Ellenberg, H. (1974). Aims and Methods of Vegetation Ecology, John Wiley \& Sons, New York

Nirmal Kumar, J.I., Rita N. Kumar, Rohit Kumar Bhoi and P.R. Sajish (2010). Tree species diversity and soil nutrient status in three sites of tropical dry deciduous forest of western India. Tropical Ecology, 51: 273-279.

Odum, E.P. (1971). Fundamentals of Ecology. 3rd edn. W. 
B. Saunders Co., Philadelphia, USA.

Pattanayak, S., Sills, E.O., Mehta, A.D. and Kramer, R.A. (2003). Local uses of parks: uncovering patterns of household pro-duction from forests of Siberut, Indonesia. Conservation and Society, 1: 209-222.

Phillips, O.L., Hall, P., Gentry, A.H., Sawyer, S.A. and Vas-quez, R. (1997). Species richness, tropical forest dynamics and sampling: response to Sheil. Oikos, 79: 183-190.

Rao, P., Barik, S.K., Pandey, H.N. and Tripathi, R.S. (1990). Community composition and tree population structure in a subtropical broad-leaved forest along a disturbance gradient. Vegetatio, 88: 151-162.

Sagar, R., Raghubanshi, A.S. and Singh, J.S. (2003). Tree species composition, dispersion and diversity along disturbance gradient in a dry tropical forest region of India. For. Ecol. Manage., 186: 61- 71.

Sahu, S.C., Dhal, N.K. and R.C. Mohanty. (2012). Tree species diversity, distribution and population structure in a tropical dry deciduous forest of Malyagiri hill ranges, Eastern Ghats, India. Tropical Ecology, 53(2): 163-168

Sahu, P.K., Sagar, R. and Singh, J.S. (2008). Tropical forest structure and diversity inrelation to altitude and disturbance in a Biosphere Reserve in central India. Applied Vegetation Science, 11: 461-470.

Sahu, S.C., Dhal, N.K., Reddy, C.S., Pattanaik, C. and Brahmam, M. (2007). Phytosociological study of tropical dry deciduous forest of Boudh district, Orissa, India. Research Journal of Forestry, 1: 66-72.
Shannon, C.E. and Weaver, W. (1963). The mathematical Theory of Communication.University of Illinois Press, Urbana USA. pp. 117.

Sheil, D. (1999). Tropical forest diversity, environmental change and species augmentation: after intermediate disturbance hypothesis. Journal of Vegetation Science, 10: 851-860.

Simpson, E.H. (1949). Measurement of diversity. Nature, 168: 688

Singh, J.S., Singh, S.P., Saxena, A.K. and Rawat, Y.S. (1984). The forest vegetation of Silent valley, India. Tropical Rainforest. The Leed Symposium, 25-52.

Singh, L. and Singh, J.S. (1991). Species structure, dry matter dynamics and carbon flux of a dry tropical forest in India. Annals of Botany, 68: 263-273.

Singh, S.P., Rawat, Y.S. and Garkoti, S.C. (1997). Failure of brown oak (Quercus semicarpifolia) to regenerate in the Central Himalaya: a case of environmental semi-surprise. Current Science, 73: 371-374.

van Schaik, C.P., Terborgh, J. and Dugelby, B. (1997). The silent crisis: the state of rain forest nature preserves. In: Kramer, R. van Schaik, C. \& Johnson, J.(eds.) Last stand: protected areas and the defense of tropical biodiversity, pp. 64-89.

Visalakshi, N. (1995). Vegetation analysis of two tropical dry evergreen forests in southern India. Tropical Ecology, 36: 117-127. 